\title{
JONGO DE ITAPEMIRIM E SUA RELAÇÃO COM A EDUCAÇÃO ${ }^{1}$
}

\author{
José Geraldo Oliveira Mion ${ }^{2}$
}

Resumo: Este artigo constitui um esboço sobre a prática do jongo - manifestação folclórica presente em alguns municípios da Região Sudeste do Brasil, enquanto sugestão de educação para alunos da Escola Municipal de Ensino Fundamental "Narciso Araújo". Seu objetivo principal é contribuir, de forma significativa, através da Educação, com a sustentação da memória da cultura popular local, neste caso, o folclore trazido por africanos que foram escravizados no Brasil, enquanto marca de identidade da população de uma comunidade específica, o Bairro Santo Antônio. Trata-se de uma pesquisa de campo abalizada em estudos de diversos pesquisadores, entre eles, historiadores e jongueiros antigos, que ponderam o problema, além de ir de encontro ao que determina a Lei 10.639/03, que menciona a obrigatoriedade da temática "história e cultura afro-brasileira" na rede de ensino.

Palavras-chave: jongo; Itapemirim; educação.

\section{JONGO OF ITAPEMIRIM AND ITS RELATIONSHIP WITH EDUCATION}

\begin{abstract}
This article is an outline of the practice of the jongo - folkloric manifestation present in some municipalities of the Southeast Region of Brazil, as a suggestion of education for students of the School Municipal School of Elementary Education "Narciso Araújo". Its main objective is to contribute significantly through education, with the support of the memory of local popular culture, in this case, the folklore brought by Africans who were enslaved in Brazil, as a mark of identity of the population of a specific community, the Bairro Santo Antônio. This is a field research based on studies of several researchers, including historians and ancient jinguiros, who ponder the problem, in addition to meeting what is determined by Law $10.639 / 03$, which mentions the obligatory nature of the theme "history and Afro-Brazilian culture "in the education network.
\end{abstract}

Keywords: jongo; Itapemirim; education.

\section{JONGO DE ITAPEMIRIM ET SA RELATION AVEC L'ÉDUCATION}

Résumé: Cet article est un croquis de la pratique de la manifestation jongo-folklorique présente dans certaines municipalités de la région du sud-est du Brésil, en tant que suggestion d'éducation pour les étudiants de l'école municipale d'éducation primaire "Narciso Araújo". Son objectif principal est de contribuer de manière significative à travers l'éducation, avec le soutien de la mémoire de la culture populaire locale, en l'occurrence le folklore apporté par les Africains asservis au Brésil, en tant que marque d'identité de la population d'une communauté spécifique, Bairro Santo Antônio. Il s'agit d'une étude de terrain basée sur les études de plusieurs chercheurs, y compris des historiens et d'anciens jinguiros, qui réfléchissent au problème, en plus de respecter ce qui est défini par la loi 10.639/03, qui mentionne le caractère obligatoire du thème "histoire et culture afro-brésilienne "dans le réseau de l'éducation.

Mots-clés: jongo; Itapemirim; éducation.

\footnotetext{
${ }^{1}$ Trabalho de Conclusão de Curso apresentado ao curso de licenciatura em Artes Visuais em EAD do Centro de Artes da Universidade Federal do Espírito Santo em 14 de julho de 2012.

${ }^{2}$ Especialista em História e Cultura Afro-Brasileira pela FETREMIS. Ator, diretor teatral, escritor, colunista e jornalista E-mail: josegeraldo2005@hotmail.com
} 


\section{JONGO DE ITAPEMIRIM Y SU RELACIÓN CON LA EDUCACIÓN}

Resumen: Este artículo constituye un esbozo sobre la práctica del jongo - manifestación folclórica presente en algunos municipios de la Región Sudeste de Brasil, como sugerencia de educación para alumnos de la Escuela Municipal de Enseñanza Fundamental "Narciso Araújo". $\mathrm{Su}$ objetivo principal es contribuir de forma significativa a través de la Educación, con la sustentación de la memoria de la cultura popular local, en este caso, el folclore traído por africanos que fueron esclavizados en Brasil, como marca de identidad de la población de una comunidad específica, Barrio Santo Antônio. Se trata de una investigación de campo abalizada en estudios de diversos investigadores, entre ellos, historiadores y jinetes antiguos, que ponderan el problema, además de ir de acuerdo a lo que determina la Ley 10.639/03, que menciona la obligatoriedad de la temática "historia y cultura afro-brasileña "en la red de enseñanza.

Palabras clave: jongo; Itapemirim; educación.

\section{INTRODUÇÃO}

Por considerarmos a possibilidade de sair do plano teórico-especulativo e relacionar a teoria com dados da realidade foi utilizado como metodologia nesta pesquisa o estudo de caso, numa proposta quantitativa. $\mathrm{O}$ foco foram apresentações do Grupo de Jongo Mirim "Chrispiniano Balbino Nazareth" na escola e em espaços alternativos, bem como entrevistas dos alunos.

O estudo focalizou, além dos jongueiros mirins que são alunos da EMEF "Narciso Araújo", demais estudantes, o que possibilitou ampliar a possibilidade de observação e registro de performances e produção de mais dados para concluir que o jongo é inventado e/ou reinventado dentro do universo de atuação na comunidade escolar.

Durante meu percurso acadêmico constatei que os alunos desvelam-se e revelam-se por meio de manifestações expressivas, cabendo às instituições escolares e aos professores, oportunizar-lhes momentos de criação, compreensão, imaginação e ressignificação.

Percebi que a relevância da arte e seu fazer artístico não se limitam ao simples papel recreativo, mas devem ser compreendidos como instrumentos pedagógicos que viabilizam e contribuem para o desenvolvimento dos meninos e meninas, que ampliam seus olhares em relação ao mundo, seu potencial cognitivo e seu emocional, entre outros. 
Acredito numa educação centrada na dominação cultural, o multiculturalismo reconhece a alteridade e o direito à diferença dos grupos minoritários, como negros, índios, homossexuais, mulheres, deficientes físicos e outros, que se sentem excluídos do processo social, sendo assim

[...] Como educadores, temos a obrigação não só de conhecer os mecanismos da dominação cultural, econômica, social e política, ampliando os nossos conhecimentos antropológicos, mas também de perceber as diferenças étnicoculturais sobre essa realidade cruel e desumana. (Oliveira, 200133)

Mesmo não sendo o único espaço de integração social, a escola é um espaço privilegiado para que crianças, jovens e adultos de todas as camadas populares tenham acesso ao conhecimento científico e artístico, do saber sistematizado e elaborado, do qual a população pobre e negra é excluída por viver num meio social desfavorecido.

\section{CANTOS DE ESCRAVIDÃO}

Século XVI... Eles chegavam cantando, mesmo amontoados nos porões dos navios negreiros! Não, ainda não era o jongo! Era o início da escravidão negra africana no Novo Mundo. Como se mercadorias fossem, os negros eram transportados em condições desumanas. Os que morriam antes do desembarque, no Brasil, eram lançados ao mar.

Os capitães os encorajavam à dança e à música, para reduzir o risco de depressão e morte durante a viagem! Desde então, foram despojados de seus pertences, aliás, a vida já não mais os pertencia! Apenas o canto lhes restara. Nele, buscavam sentimento de familiaridade e refúgio. Estavam fadados ao sofrimento e à resistência. Sabe-se que, tanto quanto fossem submetidos às tarefas árduas e tediosas, mais cantavam, assim como os seus pais e seus avós! Transbordavam musicalidade. Tristes ou alegres, esperançosos ou doentes, lá estava a canção - o júbilo, a voz! Para aliviar a fadiga e monotonia, cantavam e, acredite, produziam mais e melhor!

Quando proibidos, cantavam escondidos, quando liberados, cantavam e dançavam, até mesmo nas poucas horas de descanso ou durante o tempo nas lavouras. Muitas vezes as músicas tinham letras voltadas para o religioso. Faziam percussão

\footnotetext{
${ }^{3}$ Oliveira, Eliana. Identidade, intolerância e as diferenças no espaço escolar: questões para debate. Disponível em: <http://www.espacoacademico.com.br/007/07oliveira.htm> Acesso em: 14 nov. 2011.
} 
corporal para marcar tempos e ritmar as músicas, pois não tinham instrumentos musicais, além de tambores.

A famigerada ganância dos portugueses gerou, desde os primórdios da colonização, o sistema escravocrata, mutilando, exterminando milhares de negros africanos que, aqui, chegaram cantando, condenados a uma sobrevida e à desgraça que teriam de enfrentar pela frente... "vida de gado: povo marcado, povo feliz".

Processos a que foram submetidos como a saudade dos entes queridos e separados e outras centenas de atrocidades fizeram com que o negro criasse letras tristes e melancólicas que retratavam sua realidade, a quem, hoje, dá-se o nome de jongo! Em círculo, batiam palmas e o tocar dos tambores propiciava o agrupamento de escravizados, no entanto, até isso fora proibido em 1833, sob a alegação de que o som dos atabaques pudesse atrair cativos de fazendas mais distantes.

Muito criativos, os negros passaram a utilizar qualquer objeto que produzisse som e que pudesse servir como instrumento de percussão: peças de cerâmica e ferro, conchas, pedras, latas, pedaços de madeira. O lazer dos escravizados era marcar, ao ritmo da dança, cantorias entoadas e compassadas como toque das mãos no tambor de couro, arrastando os pés no chão, em dupla, ou sozinhos, rodeados, onde homens e mulheres batiam palmas para amenizar o lamento vivido nas senzalas...

\section{JONGO DE ITAPEMIRIM - MARCA IDENTITÁRIA DA COMUNIDADE DE SANTO ANTÔNIO}

O jongo é uma manifestação cultural que integra canto, dança circular e percussão de tambores, confeccionados a partir de tronco de madeira e couro de animal. Sua origem vem das antigas senzalas das fazendas produtoras de cana-de-açúcar e posteriormente de café do Sudeste brasileiro.

Nesta época, o jongo era uma expressão poética e, ao mesmo tempo, uma forma de comunicação baseada em "pontos" enigmáticos criados por negros bantu-angoleses que, assim, alimentavam uma complexa rede de resistência, bem como um espaço para exercitarem a sua sociabilidade em meio à situação de cativeiro.

Percebo que o Jongo, com muita relevância, é manifestação cultural presente em Itapemirim, antes bastante difundida, e atualmente caindo no esquecimento ainda não aludido nesta. Com a pretensão de resgatar tradições da comunidade jongueira e suas 
práticas na comunidade quilombola de Graúna, em Itapemirim e em especial, a manutenção deste folguedo no Bairro Santo Antônio é que me lancei neste projeto.

O jongo, manifestação folclórica afro-brasileira cuja prática remonta aos escravizados das fazendas de café, em Itapemirim, Espírito Santo, esteve fora de atividade por décadas, apesar de toda uma importância histórica para a região.

A reinserção desta cultura popular na comunidade ocorreu após o jongo ter sido proclamado Patrimônio Cultural do Brasil em novembro de 2005 pelo Instituto do Patrimônio Histórico e Artístico Nacional (Iphan). Um ano depois, ou seja, em 2006, Mestra Quequê ${ }^{4}$, jongueira desde os oito anos de idade e contando à época com 60 , toma a iniciativa de resgatar a arte junto aos demais jongueiros, já que o jongo estava há anos e anos fora de atividade.

Sem obter êxito em sua empreitada, Mestra Quequê reuniu um grupo de crianças moradoras da Comunidade de Santo Antônio, conhecida como Arraial dos Macacos, e passou a ensinar a dança do jongo aos meninos e meninas do bairro.

Os velhos jongueiros já não existem mais e a prática dessa arte, se não for perpetuada através da criança e do adolescente, certamente se findará, por isso, o que se propôs foi a inserção dos alunos da Escola Municipal de Ensino Fundamental "Narciso Araújo", Itapemirim, para que aos poucos os adultos possam sentir-se incentivados e motivados a retornarem ao Grupo de Jongo "Mestre Bento", inativo há décadas.

Música, dança, há toda uma manifestação de expressão artística cultural no jongo. Entre os instrumentos utilizados nessa prática, percebemos uma definição bem relevante por Guimarães e Junior,

[...] são tambores, em geral uma dupla de tambores, um grande denominado de caxambu e um pequeno denominado de candongueiro, geralmente são feitos de troncos de árvore escavados, cujas bocas são cobertas com couro de animais, bem esticados e presos com prego de ripa, tachas ou cravos. Os tambores são os instrumentos que religam os ritmos ancestrais africanos às manifestações e práticas na atualidade. (Guimarães; Moura Junior, 2011, p. 6)

Vale ressaltar que em Itapemirim, assim como em São Mateus do Sul, em Anchieta e Cacimbinha, Presidente Kennedy, os grupos de jongo utilizam três tambores. São eles:

\footnotetext{
${ }^{4}$ Cleuza Maria da Silva Gomes, principal responsável pelo Grupo de Jongo Mirim "Chrispiniano Balbino Nazareth". Titulada como "mestre" pela Comissão Espírito-Santense de Folclore.
} 
tambu, caxambu e candongueiro. O tambu é o maior e mais grave; seguido do caxambu, um pouco menor e menos grave e; por último, o menor, denominado candongueiro, cujo som é mais agudo. Usam-se apenas as mãos para percuti-los, sem auxílio de baquetas. Todos eles são afinados com o calor do fogo. Por isso é que se acende uma fogueira quando da apresentação de jongo.

O jongo, forma de expressão afro-brasileira que integra percussão de tambores, dança coletiva e práticas de magia, está presente em Itapemirim há décadas. De acordo com Manoel Peixoto ${ }^{5}$, quando da realização da primeira festa em homenagem a Santo Antônio, no ano de 1917, já na Comunidade de Arraial dos Macacos, periferia de Itapemirim, à época, centro, houve apresentação de jongo.

Outro registro que se tem sobre a existência do jongo em Itapemirim é do cronista Rubem Braga que, tratando do tema como folclore, registrou a presença do jongo no litoral sul do Espírito Santo na década de 40 do século XX. O autor teria assistido, durante a Festa das Canoas, em Marataízes, no ano de 1940, uma apresentação do jongo. Vale ressaltar que Marataízes, nesta época, pertencia ao Município de Itapemirim. Braga se surpreendeu com a quantidade majoritária de negros na dança do jongo

... no jongo quase não intervinham maratimbas, e sim pretos, moradores dos arredores. (...) Direi que no jongo em questão havia um branco, ou dois, mas sem graça. Quem mais brilhava era o preto Benedito Calunga pela maneira muito pessoal e demoníaca de pular e dansar com desespero, às vezes em pé, às vezes de cócoras (Braga, 1940, p. 79)

Também, antes mesmo do desmembramento do atual município de Presidente Kennedy, em 1963, antiga Vila de Batalha, a fogueira acesa já era sinal de que a noite ia esquentar. A chama forte aquecia (e ainda aquece) as pessoas, além de afinar os tambores.

Pouco a pouco vão chegando os tocadores, cada um com seu tambor de tora de madeira oca, couro curtido e muita força nos braços para a noite batucar. As mulheres com suas saias longas e coloridas e com o gingado que somente elas têm, também se posicionam em torno da roda que se forma para o jongo começar. Vem então a louvação e, com muito respeito, todos aguardam para iniciar a canção. O tocador em cima do tambor bate com suas mãos espalmadas, dando o ritmo e o tom. No centro está o jongueiro - solista, ele canta o "ponto" ou a cantiga, seja de improviso ou não. As mulheres acompanham dançando e respondendo à canção. E quando querem parar a dança, tocam o rosto do

\footnotetext{
${ }^{5}$ Presidente da SOMAI - Sociedade dos Moradores e Amigos de Itapemirim.
} 
tocador com a ponta da saia. Este, com um tapa no couro, para a apresentação, que não demora para recomeçar (NASCIMENTO; SANTOS, 2007, p.49)

Como símbolo de sua identidade, as comunidades reuniam-se em suas festividades em torno de uma das suas mais atraentes e tradicionais manifestações que é o jongo, revelando-se mais uma face de sua diversidade cultural.

Com o passar dos tempos, os jongueiros foram perdendo seu espaço para as novas tecnologias. $\mathrm{O}$ advento da TV e de outras mídias direciona a atenção dos moradores ao novo, o que ganha força com a ausência de uma definição das políticas públicas de cultura no Espírito Santo.

\section{Figura 1. Mestres de Jongo na Comunidade Santo Antônio ensinando os alunos}

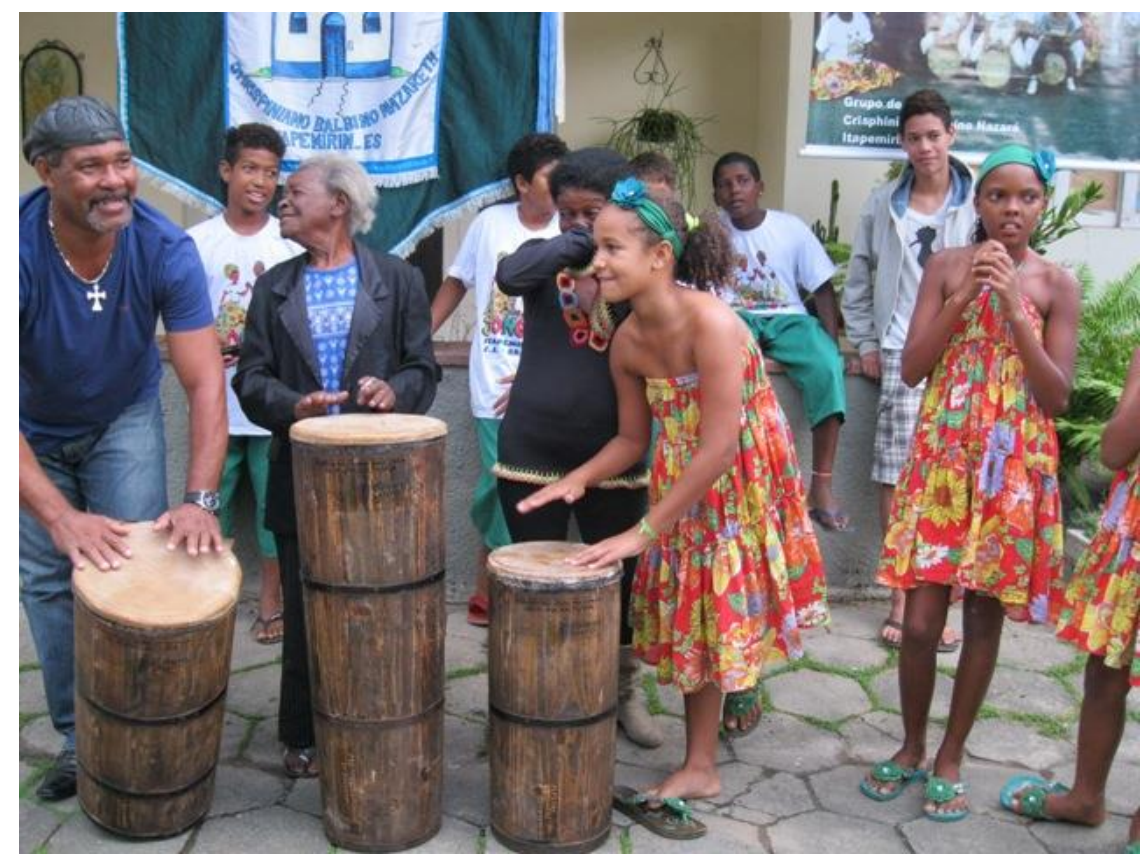

Fonte: arquivo do autor

Percebendo o desgaste, em Itapemirim foram implantadas ações voltadas ao resgate e à manutenção da prática do jongo na cidade, bem como, passou-se a desenvolver toda uma logística necessária para o fazer artístico dessa manifestação, além de desfraldar projetos culturais para comunidade quilombola de Graúna, onde estão surgindo equipes que pretendem prosseguir com o folguedo.

Assim sendo, importantes passos foram dados para a inclusão social dessas comunidades, compreendido nesse projeto, que também nasceu com a intenção do 
resgate cultural neste processo de ressignificação e/ou reinserção que proporciona a proliferação da cultura afro, em especial, a manutenção do Grupo de Jongo Mirim “Chrispiniano Balbino Nazareth”, característica marcante do bairro Santo Antônio.

As crianças, por exemplo, que durante muito tempo não podiam frequentar as rodas de jongo, hoje são estimuladas a aprender o canto e a dança de seus ancestrais. E, em muitas comunidades, não é mais necessário ser filho de jongueiro para ser considerado jongueiro.

A aproximação de pesquisadores e estudiosos, bem como, mais recentemente, de jovens das camadas médias urbanas, fez com que a participação em uma roda de jongo não estivesse mais limitada aos integrantes das comunidades jongueiras. Além disso, algumas comunidades passaram a fazer apresentações artísticas, nas quais as rodas de jongo acontecem sob a forma de espetáculo.

\section{Figura 2. Alunos da EMEF “Narciso Araújo” com o proponente na Biblioteca Pública}

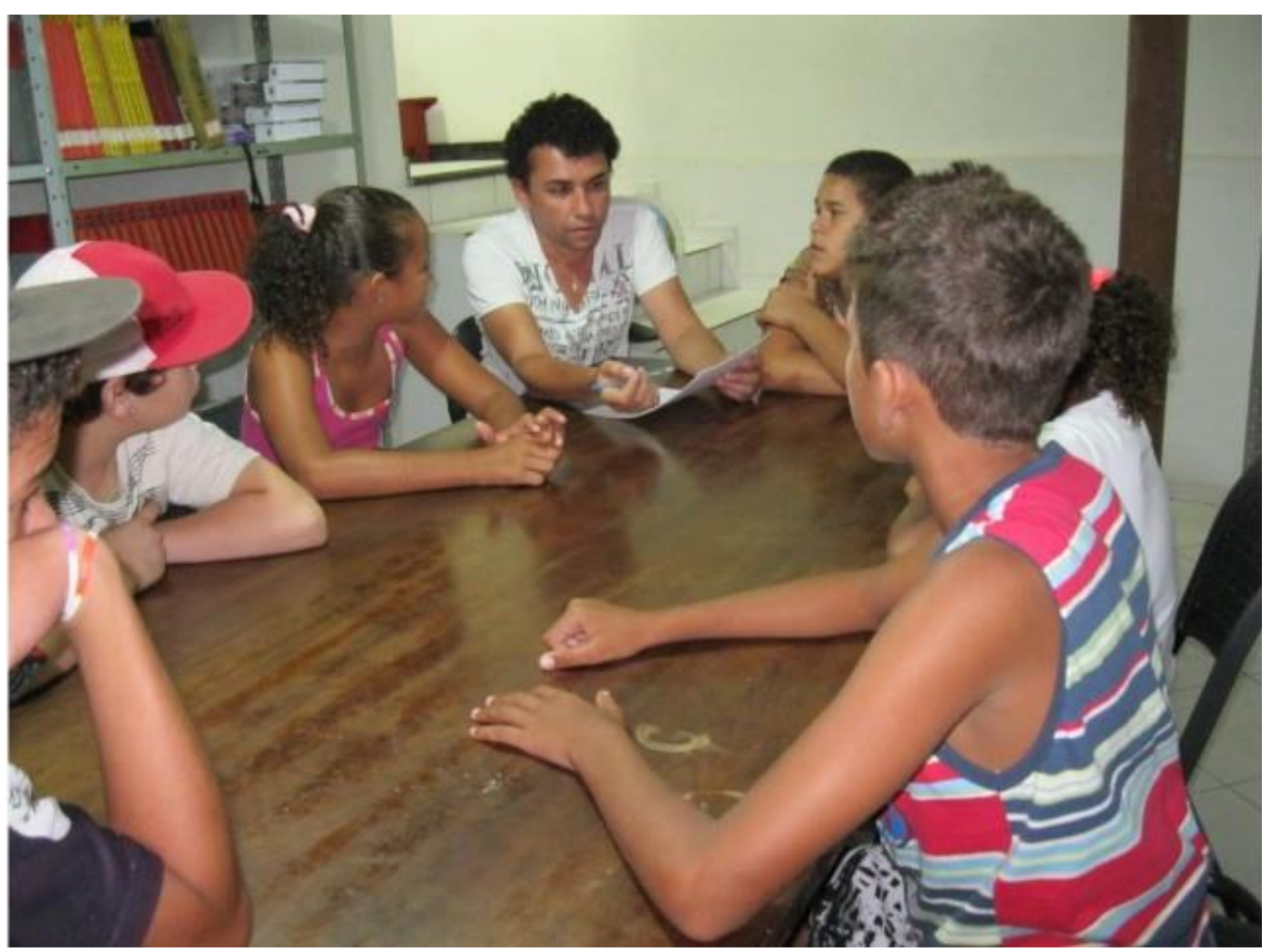

Fonte: arquivo do autor 
No Brasil, o jongo se consolidou entre os escravizados que trabalhavam nas lavouras de café e cana-de-açúcar, no Sudeste brasileiro, principalmente no vale do rio Paraíba do Sul. Nos tempos da escravidão, a poesia metafórica do jongo permitiu que os praticantes da dança se comunicassem por meio de pontos que os capatazes e senhores não conseguiam compreender. Sempre esteve, assim, em uma dimensão marginal, em que os negros falam de si, de sua comunidade, por meio da crônica e da linguagem cifrada.

A prática do jongo acontecia e ainda acontece nos quintais das periferias urbanas e de algumas comunidades rurais do Sudeste brasileiro, assim como nas festas dos santos católicos e divindades afro-brasileiras, nas festas juninas, no Divino e no dia 13 de Maio, comemorando a abolição dos escravizados.

Os jongueiros mirins são, em sua maioria, alunos da EMEF "Narciso Araújo", no entanto, não se ensina o jongo em sala de aula. Por isso nasceu esta proposta de desenvolver na educação esta arte enraizada no seio escolar, ainda que camufladamente. E foi, exatamente, pensando neste estreitamento de laços, que surgiu a proposta do ensino/aprendizado do jongo às crianças e adolescentes, alunos da EMEF Narciso Araújo, aplicando nas aulas de Artes, a técnica da dança do jongo, manifestação cultural tradicional em Itapemirim e marca identitária da Comunidade de Santo Antônio.

\section{Figura 3. João Victor Cardozo de Miranda Bento em Marataízes}

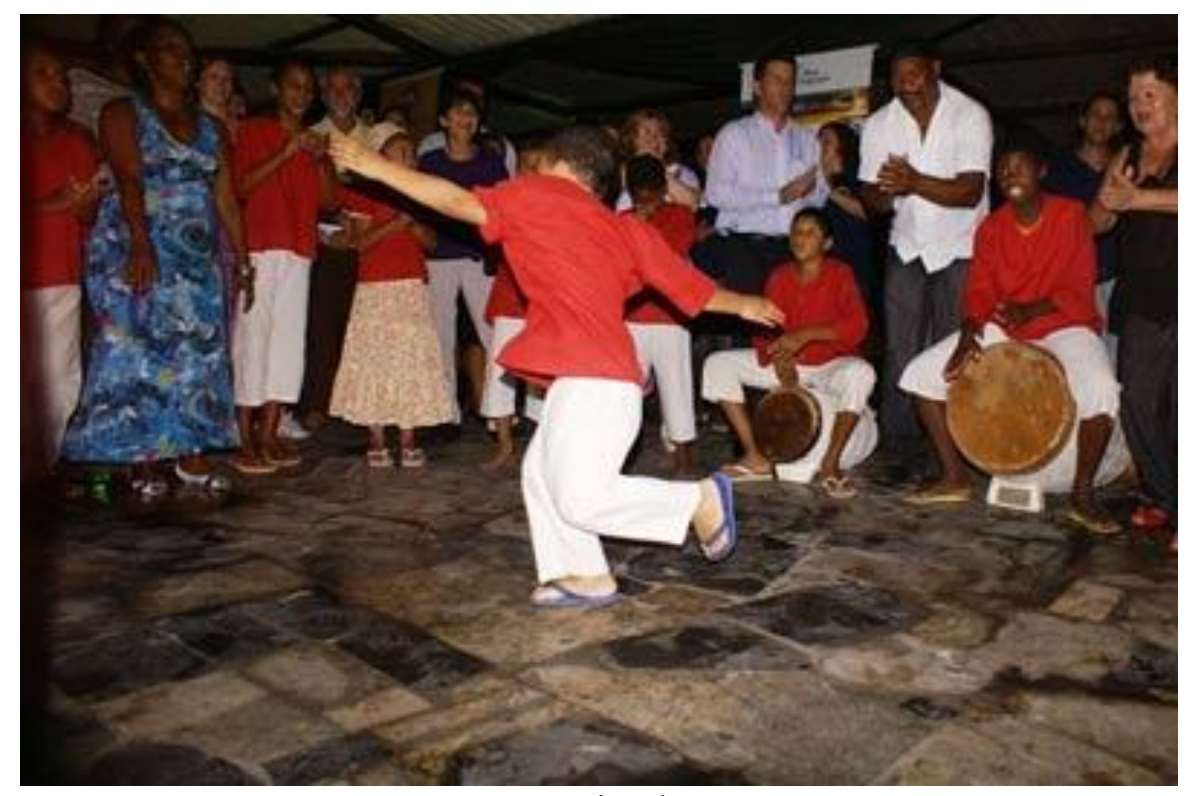

Fonte: arquivo do autor 


\section{HISTÓRIA E CULTURA AFRO-BRASILEIRA NA REDE DE ENSINO, OBRIGATORIEDADE A PARTIR DA LEI No ${ }^{0} \mathbf{1 0 . 6 3 9 / 0 3}$}

No ano de 2003, o então Presidente da República, Luis Ignácio Lula da Silva, deu um importante passo para a História do Brasil ao sancionar a Lei $\mathrm{N}^{\mathrm{o}} 10.639$, alterando, então, a Lei N ${ }^{\circ}$ 9.394, de 20 de dezembro de 1996, que estabelece diretrizes e bases da educação nacional, para incluir no currículo oficial da Rede de Ensino a obrigatoriedade da temática "História e Cultura Afro-Brasileira".

A cultura negra brasileira, mais uma vez amparada oficialmente enquanto Educação, ganha força e vem de encontro aos anseios do negro na formação da sociedade nacional, resgatando sua contribuição nas áreas social, econômica e política, a saber:

Lei $\mathrm{N}^{\circ} .10 .639 / 03$

Altera a Lei $\mathrm{n}^{\circ} .9394$ de 20 de dezembro de 1996, que estabelece as diretrizes e bases da educação nacional, para incluir no currículo oficial da Rede de Ensino a obrigatoriedade da temática "História e Cultura Afro-Brasileira". E dá outras providências. O PRESIDENTE DA REPÚBLICA Faço saber que o Congresso Nacional decreta e eu sanciono a seguinte Lei:

Art. $1^{\circ}$ - A Lei no 9.394, de 20 de dezembro de 1996, passa a vigorar acrescida dos seguintes arts. 26-A, 79-A e 79-B:

Art. 26-A. Nos estabelecimentos de ensino fundamental e médio, oficiais e particulares, torna-se obrigatório o ensino sobre História e Cultura AfroBrasileira.

$\S 1^{\circ} \mathrm{O}$ conteúdo programático a que se refere o caput deste artigo incluirá o estudo da História da África e dos Africanos, a luta dos negros no Brasil, a cultura negra brasileira e o negro na formação da sociedade nacional, resgatando a contribuição do povo negro nas áreas social, econômica e política pertinentes à História do Brasil.

$\S 2^{\circ}$ Os conteúdos referentes à História e Cultura Afro-Brasileira serão ministrados no âmbito de todo o currículo escolar, em especial nas áreas de Educação Artística e de Literatura e História Brasileiras.

$\S 3^{\circ}$ - (Vetado)"

"Art. 79-A - (Vetado)"

"Art. 79-B - O calendário escolar incluirá o dia 20 de novembro como o Dia Nacional da Consciência Negra."

Art. $2^{\circ}$ - Esta Lei entra em vigor na data de sua publicação. Brasília, 09 de janeiro de $2003 ; 182^{\circ}$ da Independência e $115^{\circ}$ da República. 
Considerando que as sociedades vivem neste mundo globalizado do século XXI, a citada Lei apresenta-se como elemento balizador da educação no Brasil, uma vez que a finalidade é "[...] criar iguais oportunidades de sucesso escolar para todos os alunos, independente de seu grupo social, étnico/racial [...]" (Gonçalves, 2006, p. 50).

Doutor e mestre em Letras, Maurício Pedro da Silva, professor de Literatura Brasileira na Uninove/SP afirma que

[...] educar para uma sociedade pluriétnica compreende fomentar práticas sociais voltadas para a convivência plena dos cidadãos; incentivar programas de inclusão socioeducacional; desenvolver políticas de reparação, por meio de ações afirmativas diversas; valorizar o patrimônio histórico-cultural das etnias marginalizadas; enfim, implementar ações que, superando os preconceitos historicamente forjados e as discriminações tradicionalmente toleradas, resgatem a auto-estima, o universo simbólico, a cidadania e a identidade racial das comunidades que compõem a sociedade brasileira, particularmente as afrodescendentes [...] (Silva, 2007, p. 43).

Concordamos com o autor que ainda afiança a necessidade de avaliação e análise dos princípios que regem a Lei $\mathrm{N}^{\mathrm{0}} 10.639 / 03$ e seus propósitos ao perceber uma série de práticas educacionais que perfazem as diretrizes pedagógicas necessárias à promoção da cultura e da história afro-brasileira e africana.

Na educação contemporânea é indispensável que se trabalhe a diferença, no entanto, percebe-se que após nove anos de sancionamento desta Lei, poucas são as instituições de ensino, públicas ou particulares, que promovem adaptações no currículo para atender às exigências da legislação. 
Figura 4. Alunos da EMEF "Narciso Araújo" com o autor e mestras jongueiras

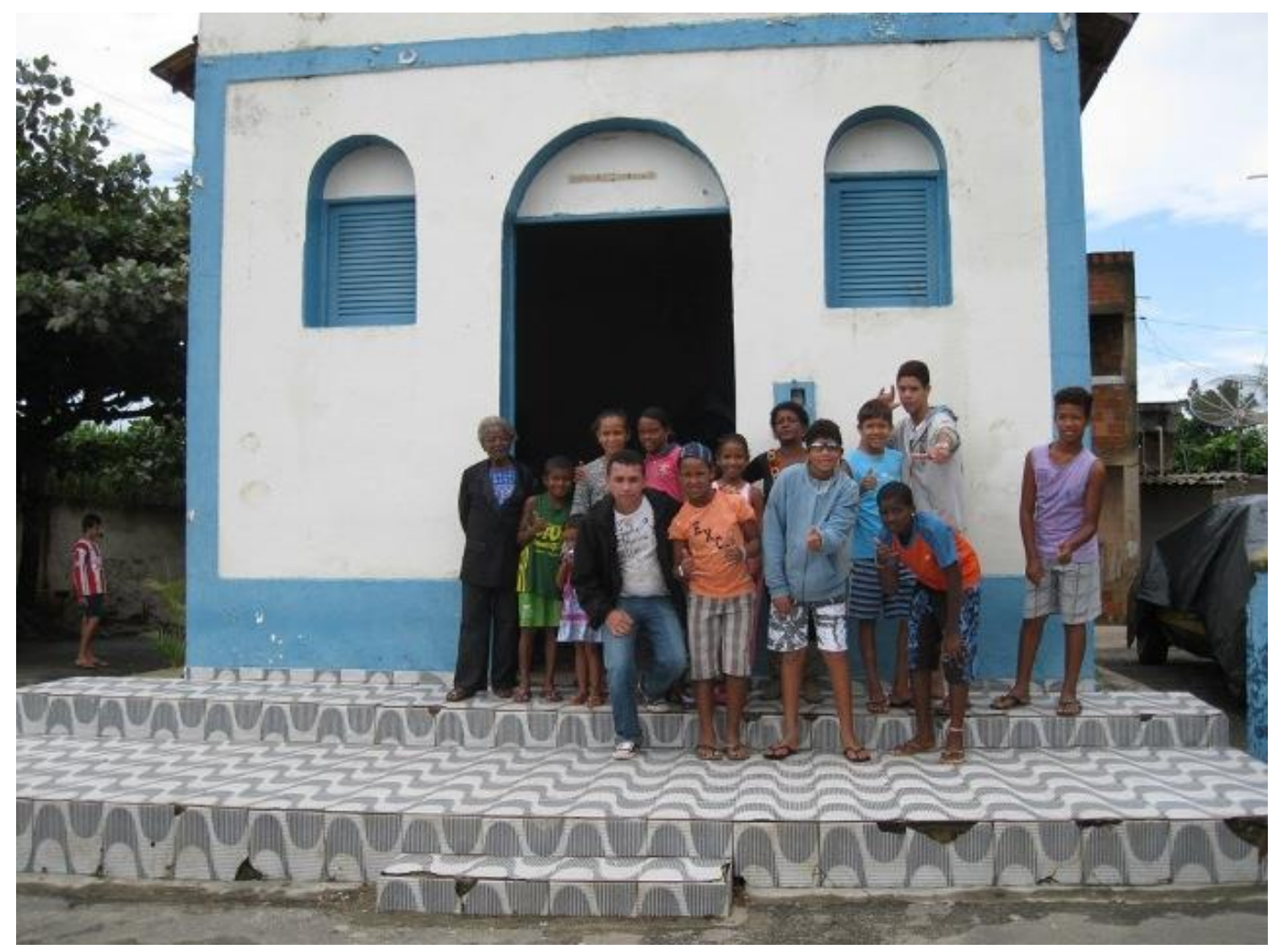

Fonte: arquivo do autor

Sendo a arte capaz de avigorar as culturas de diversos grupos inseridos na escola, alcançamos o pensamento de Ana Mae Barbosa ao enfatizar:

A arte como linguagem aguçadora dos sentidos transmite significados que não podem ser transmitidos por meio de nenhum outro tipo de linguagem, tal como a discursiva ou a científica. Dentre as artes, as visuais, tendo a imagem como matéria-prima, tornam possível a visualização de quem somos, de onde estamos e de como sentimos (Barbosa, 2005, p. 99)

Esta indicação não propendeu reduzir o ensino da arte a um mero trabalho com as culturas de origem dos grupos, mas sim realçar as variantes inflexíveis de cada uma dessas culturas e aquilatar seus subsídios na concepção daquilo que se ajustou chamar de "cultura brasileira". Assim, o ensino da arte deve incluir teores das manifestações artísticas determinadas em distintos tempo e lugares, abonando ao estudante o perpendicular à ciência e à participação social transformadora, inclusive da metodologia de aprendizagem, de maneira a conduzir nova acepção à escola, além de proporcionar um ambiente enriquecedor para o educando. 
Para início de conversa, $\operatorname{Mazoco}^{6}(\mathrm{~s} / \mathrm{d}, \mathrm{p} .146)$, referindo-se à cultura popular capixaba, proferiu em sua exposição, os seguintes trechos:

[...] Mesmo modelados pela Igreja Católica, neste folguedo como também nos jongos, caxambus, caboclinhos, bate flechas, e em manifestações de fé como a Nossa Senhora, a Iemanjá, São Jorge, Oxum, Iansã, Santa Bárbara, Oxóssi, Cosme e Damião, realizada por meio de seitas como o candomblé e a macumba, os negros nos legaram um enorme universo mágico e cultural que se expressa também nas nossas crendices e superstições, na culinária, com seus beijus, acarajés, cuscuz, vatapás, no artesanato e no jeito diferente de falar o português, ensinado pelo capataz aos berros ou sussurrado nas senzalas, pelos descendentes de índios e negros ladinos [...].

Segundo o autor há um longo percurso a seguir para que a sociedade valorize suas raízes, suas tradições. Nesta perspectiva, falta no Espírito Santo uma definição das políticas públicas de cultura.

As ações não têm rumo definido. Não há projetos que expressem valores, concepções e ideias do mundo para o Estado. Na sua maioria as instâncias de administração cultural são só escritórios de articulação de projetos e eventos de promoção pessoal e política, quando não de corrupção (s/d, p. 151).

Duarte Junior também é enfático ao afirmar que no jogo da cultura homem e cultura não se separam, “[...] homem e cultura estão indissoluvelmente ligados: só há uma cultura através do homem, e o homem só existe pela cultura [...]” (Duarte Júnior, 1995, p. 50), Também, o autor, pontua: “[...] É nela que nos tornamos humanos, que aprendemos a organizar e construir o mundo, atribuindo-lhe significações [...]” (1995, p. $51)$.

O autor afiança ainda que, "[...] ao criar uma cultura, os indivíduos ou comunidades projetam diante de si, em obras e objetos, um sistema organizado de valores e de significações que revelam sua visão de mundo e sua concepção de vida" (Duarte Júnior, 1995, p. 52). Embora os traços do jongo atual sejam semelhantes aos praticados décadas passadas, inserem-se na contemporaneidade novas dinâmicas sem perder a essência do belo,

\footnotetext{
${ }^{6}$ Historiador, especialista em Políticas Públicas, presidente da Comissão Espírito-Santense de Folclore.
} 
[...] É de se notar, portanto, que o homem "civilizado" não é uma obra acabada. Ele permanece em constante processo de alteração. Enquanto constrói o mundo, transformando a face do planeta, constrói e transforma a si próprio [...] (Duarte Júnior, 1995, p. 56)

Sendo assim percebemos que a cultura é fonte para construção de conhecimentos, novas descobertas e significações para todos que estão inseridos nela; transformamos e somos modificados por ela. Para Laraia (2004),

[...] cada cultura segue seus próprios caminhos em função dos diferentes eventos históricos que enfrentou. A partir daí a explicação evolucionista da cultura só tem sentido quando ocorrer em termos de uma abordagem multilinear (Laraia, 2004, p. 36).

Neste sentido, contrariando o pensamento leigo, Laraia afirma que a noção de cultura é comum entre os diferentes setores da nossa população adquirida, também, graças à transmissão genética, mas, sobretudo, ao espaço em que vivem, o que interfere nas criações,

[...] O homem é o resultado do meio cultural em que foi socializado. Ele é um herdeiro de um longo processo acumulativo, que reflete o conhecimento e a experiência adquiridos pelas numerosas gerações que o antecederam. A manipulação adequada e criativa desse patrimônio cultural permite inovações e as invenções. Estas não são, pois, o produto da ação isolada de um gênio, mas o resultado do esforço de toda uma comunidade (Laraia, 2004, p. 45).

Ao sugerir o jongo enquanto proposta de trabalho no ensino das Artes Visuais adotei por base uma vez mais o pensamento do autor:

[...] o importante, porém, é que deve existir um mínimo de participação do indivíduo na pauta de conhecimento da cultura a fim de permitir a sua articulação com os demais membros da sociedade. Todos necessitam saber como agir em determinadas situações e, também, como prever o comportamento dos outros (Laraia, 2004, p. 82).

Daí nosso pensar em fazer esta intervenção, com os alunos, onde possibilitar o encontro deles com os jongueiros mirins foi proposta que permeou nosso desejo de contribuir para uma geração que valoriza e preserva suas tradições, mas... Afinal, o que é jongo? Os negros trazidos da África e que no Brasil foram escravizados trabalhavam sob açoites e chicotes. Eram castigados nos troncos por seus feitores ao serem capturados pelos capitães do mato, na tentativa de fuga! Para suavizar tanta dor e 
sofrimento, quando podiam, dançavam ao som de uma cantoria muito particular: o jongo ou caxambu!

O jongo já foi considerado como dança de "preto", de "negro", de "pobres", de "cachaceiros" e, associado à "macumba". Sempre sofreu com o preconceito racial que se manifestava e ainda se manifesta ou na ausência de direitos básicos e na subserviência aos poderes locais para a garantia da sobrevivência ou na garantia ainda desigual entre negros e brancos desses direitos.

O jongo, no entanto, é música, é dança, é arte, é folclore, é cultura de raiz africana. O cântico entoado pelo jongueiro é, talvez, seu maior símbolo! Oral, falado ou cantado pelo solista, com versos livres improvisados, tem o refrão respondido por todos. O tempo do cativeiro é relembrado em uma série de pontos, por meio de metáforas e um linguajar próprio, ou seja, mais do que manifestação cultural, o jongo tem papel central na valorização e no desenvolvimento das comunidades quilombolas e/ou afrodescendentes. Do som dos atabaques à dança em roda, da reverência aos anciãos e aos antepassados (pretos velhos) à malícia dos versos.

Em Itapemirim a comunidade jongueira ultrapassa percalços e objetiva identificar o papel das políticas sociais empreendidas pela Municipalidade, conforme a Lei Municipal No . 2.235, de 10 de março de 2009 e através da União, como é o caso da Lei ${ }^{\circ} 10.639 / 93$, do Governo Federal.

\section{JONGO - PATRIMÔNIO IMATERIAL BRASILEIRO}

Apesar de toda a luta por sua manutenção no decorrer do século XX na Região Sudeste, o resgate desse folguedo só se tornou "definitivamente" possível graças à iniciativa, no limiar do século XXI, do Patrimônio Histórico Artístico Nacional (IPHAN), por meio do Centro Nacional de Folclore e Cultura Popular, que o tornou patrimônio imaterial brasileiro.

Através do jongo, os escravizados se comunicavam por meio de mensagens cifradas, o que o levou a ser proibido em algumas localidades. Durante a escravidão, segundo pesquisa feita pela especialista em História da África e do Negro no Brasil, 
Luciana da Conceição Figueiredo, o jongo sofreu grande repressão das autoridades. Após a abolição, o preconceito continuou existindo.

Luciana relata que foi a partir de 1930 que o jongo passou a ser objeto de estudo de vários folcloristas que reconheceram nele, uma importante tradição afro-brasileira prestes ao desaparecimento, à medida que a última geração de escravizados ia morrendo. A intervenção, no entanto, e a persistência não são somente pela abolição da escravatura. E jamais serão! A partir da metade do século XIX a escravidão no Brasil passou, sim, a ser contestada pela Inglaterra, porém, a luta continua até os dias atuais, pela manutenção de suas crenças e costumes e mesmo, até pelo resgate de seus saberes e fazeres.

\section{JONGO E SUA DINÂMICA}

À época das fazendas de café, os Senhores de Engenho açoitavam os negros, de forma indiscriminada e covarde, porém, apesar dos "ais", os escravizados, a tudo resistiam. O jongo era, para eles, uma maneira que encontraram para se comunicarem sem serem entendidos pelos tiranos. Os negros desenvolveram uma forma de comunicação baseada em "pontos" enigmáticos que, assim, alimentavam uma complexa rede de resistência, bem como, um espaço para exercitarem a sua sociabilidade em meio à situação de cativeiro.

Os anos se passaram, mas a tradição, Itapemirim (ES), se mantém. Os grupos de jongo utilizam três tambores, sendo eles o tambu (ou angoma), o caxambu e o candongueiro. O tambu é o maior e mais grave; seguido do caxambu, um pouco menor e menos grave e; por último, o menor, denominado candongueiro, cujo som é mais agudo.

Os jongueiros usam apenas as mãos para percutilos, sem auxílio de baquetas. Todos são afinados ao calor do fogo, motivo pelo qual, costuma-se acender uma fogueira durante as apresentações. Nos tempos da escravidão, quando a comunicação era restrita, os escravizados usavam essa dança para passar recados, relatar acontecimentos ou até divulgar decisões dos líderes das comunidades, por isso, o 
elemento essencial do jongo sempre foi o uso da metáfora, da poesia como uma linguagem codificada, da qual, não iniciados, não conseguem compartilhar.

Atualmente, sem perder a alegria, o jongo apresenta-se, antes de tudo,como já mencionado, a celebração à vida e assim, seguem as expressões ligadas intimamente à vida das comunidades, aos seus ciclos, aos traços das antigas contradanças, ao extravasamento de alegria, comemoração de vitórias. Assim se perpetua (ou tenta) a dinâmica do jongo, que canta a liberdade em pleno século XXI: gesto de fé e de esperança que remetem ao passado de dor e de ais, mas que aguarda dias melhores, dias de paz, dias de sol, de justiça, de perdão!

\section{JONGO E A DIÁSPORA NEGRA NO BRASIL}

Ao ler o artigo "Diáspora Africana: ações presentes e perspectivas para o futuro", enquanto dossiê temático publicado na Revista da ABPN | Jul - Out 2018 | v. 10 n. 26 (2018), constato que o jongo, como a maior parte das tradições afro-brasileiras, rearticulou seu universo simbólico na diáspora através de elementos de diferentes etnias, uma vez que o processo histórico de escravidão no Brasil tentou não permitir a reorganização cultural por "nações" africanas, devido ao desmantelamento das famílias, acrescido ainda de um relativo confinamento em que viviam os negros escravizados nas fazendas.

No Brasil, as senzalas e terreiros, inicialmente, delimitados como espaços de confinamento, acabaram por se configurar como território de organização social e lugar de afirmação da cultura negra, pois foi ali que muitas práticas de matriz africana foram desterritorializados, empreenderam a partir de seus corpos e memórias um processo de reconstrução de suas identidades e territórios, de maneira que as culturas, as festas, os rituais, fazeres e saberes afro-brasileiros têm origem no aspecto da imaterialidade e da oralidade dessas memórias.

Quando da colonização do Brasil, a Europa tinha necessidade de ouro e prata. A atividade mercantilista do tráfico de africanos visava permitir a acumulação do capital na Europa e, também, para a Igreja Católica, que naquela época, justificou com o 
argumento da "salvação da alma", que pelo batismo, buscou minorizar a força do ato do tráfico.

Outras formas de aceitação pacífica do tráfico, segundo Koster, no Brasil, havia muita gente que foi convencida de que os africanos eram salvos da morte pelos mercadores de escravizados e, se não fossem comprados pelos europeus seriam assassinados pelos seus próprios conterrâneos. Deixando Itapemirim, vamos fazer um rápido passeio ao nordeste brasileiro. Utilizando de técnica irracional de plantio, o português incendiou o Nordeste para plantação de cana-de-açúcar, apelando para a coivara, pois precisava de mais terras para plantar, destruiu matas, fez perder a maior parte das madeiras de lei, modificou o clima, o regime dos rios, propiciando as grandes secas atuais e, ainda, eliminou a grande parte da fauna regional.

Enquanto o português provocava esse desastre ecológico o negro africano escravizado, no Brasil, era produto e produtor e o país se transformou no maior produtor de açúcar do mundo em torno de 1550, pelo trabalho do povo africano, tornando-se a liderança do mercado exterior. O açúcar brasileiro já saía pronto para o consumo, era açúcar claro em contraste com o açúcar mascavo, produzido nas Antilhas, que era escuro, o brasileiro era quase branco, mas quem produziu todo este volume de riqueza foram os africanos. Deste modo, o mercado do açúcar brasileiro chamou a atenção de outras potências europeias.

\section{O PROJETO EDUCATIVO: CONTEXTUALIZAÇÃO DA ESCOLA E DOS SUJEITOS}

O educandário escolhido para desenvolver a pesquisa está localizado próximo a estabelecimentos comerciais e atende a uma clientela composta por famílias carentes, oriundas da zona rural e periferia de Itapemirim, como o bairro Rosa Meirelles e o próprio Santo Antônio.

Nossas ações foram então direcionadas aos alunos, não de uma série específica, mas sim, com estudantes interessados em aprender o jongo, independente de sua série, vez que esta arte agrega e encanta pessoas de todas as idades e classes sociais.

A realidade dos alunos itapemirinenses no contraturno escolar é, na sua grande maioria, desesperadora. A prática do jongo chama à responsabilidade, não somente 
crianças e adolescentes, como pais e professores. A comunidade tem percebido a motivação por parte da escola e sua participação neste novo processo de ressignificação e re-educação tem sido efetiva.

O cidadão de hoje, certamente se tornará um adulto produtivo amanhã, se o professor, pais e responsáveis, entenderem que é tarefa de todos, a educação como colaboração para que os alunos construam sua identidade, seu caminho pessoal e profissional.

De forma geral, alguns alunos permanecem sozinhos quando não estão na escola, uma vez que os pais saem cedo para trabalhar, já outra parcela destes estudantes está inserida no PETI - Programa de Erradicação do Trabalho Infantil. Isso, certamente, colabora para que se tornem mais independentes, assumindo tarefas cada vez mais cedo, privando-se de lazer, cultura, arte e entretenimento.

\section{ANÁLISE E INTERPRETAÇÃO DE DADOS: PRESSUPOSTOS TEÓRICOS E METODOLÓGICOS}

Dewey em seu livro "Democracia e educação" (1959) aponta para a diferenciação de duas vertentes da educação, entendendo que uma sociedade que preza pela mudança social, isto é, pela democracia, não deve sobrepor uma pela outra. A educação formal (intencional, sistemática) e a não-formal (casual e assistemática) devem coexistir. Dewey (1959), apesar de concordar com a relevância da educação formal, principalmente nas sociedades complexas, atenta para o perigo da instituição formal "separar" o ensino da experiência da vida cotidiana.

Já Geertz (1989) compreende a cultura como uma ciência interpretativa à procura de significados e de interpretações de símbolos. Sendo assim, compreendemos que o jongo e o processo de ensino-aprendizagem que o envolve se tornam uma ferramenta imprescindível para analisarmos a conjuntura atual de disputa e de defesa dos territórios das comunidades quilombolas jongueiras. Devemos estar atentos a esse movimento de formação quilombola por meio da cultura, sobretudo do jongo, uma vez que nessa prática cultural estão presentes significados e símbolos de pertencimento identitário e étnico. 
Duarte Junior (1995) entende que deve existir um elo entre relações interculturais e educação. Trata-se, assim, de apresentar ao educando visões "parciais" da realidade, de "formá-lo" para que sua atuação se dê no campo especifico de uma peculiaridade.

\section{DESCOBERTAS}

Ao realizar a pesquisa de campo na "Narciso Araújo" e na Comunidade de Santo Antônio, várias foram as descobertas, entre elas, que se dança o jongo espontaneamente, no dia-a-dia ou em eventos comemorativos, como datas religiosas, casamentos, festas rurais e eventos diversos, no entanto, o número de participantes é limitado. Outra importante descoberta foi que a prática do jongo é mantida entre membros da mesma família, o que, de certa forma, dificulta sua disseminação e diante dessa dificuldade me propus levar a prática do jongo e seu aprendizado aos alunos ensinando-lhes a dança na escola, objetivando maior aderência dos adolescentes, bem como sua propagação.

Também foi descoberto o preconceito na própria comunidade e contrastando, o apoio incondicional à Mestra Quequê. A minoria a apóia, enquanto a grande maioria vê na prática do jongo apenas prática de magia e macumba. Além de todo este contexto, descobrimos também que a prática do jongo, apesar de, está intimamente ligada à ausência de políticas públicas e, se por um lado pode-se afirmar que se instaura uma rede de resgate e perpetuação do jongo, por outro se deve refletir sobre os caminhos pelos quais os quilombolas vêm conseguindo perpetuar suas lutas.

Sendo assim, os mediadores que "ritualizam e negociam as categorias portadoras de identidades para ação na esfera pública, propondo, desta forma, articulação entre cultura e política” (Monteiro, Arruti e Pompa, s/d, p. 32), se tornam peças fundamentais nesse processo. Indo ao encontro da adesão ao movimento quilombola por meio do jongo, o presidente da Associação de Moradores da Comunidade Quilombola de Graúna, Everaldo Leão ${ }^{7}$ diz que: “O jongo trabalha a questão mesmo do fortalecimento da luta. Nossas crianças e jovens da Comunidade Quilombola de Graúna conheceram o trabalho desenvolvido no Bairro Santo Antônio e querem implantar também em nossa localidade".

\footnotetext{
${ }^{7}$ Everaldo Leão da Silva, secretário geral do Movimento Quilombola e coordenador da Associação Comunitária Quilombola de Graúna. Entrevista in loco, 14/10/2011.
} 
Não foi trabalhado o folclore com os alunos num processo de ensinoaprendizagem do jongo em espaços de educação não-formais sem qualquer relação com a educação formal, sendo até mesmo recusados e evitados pela direção e pelos professores das escolas que atendem tais comunidades. Antes de tudo, a democracia. O que se propôs foi a elaboração de um projeto voltado ao desenvolvimento e perpetuação de saberes tradicionais e culturais, dentre os quais o jongo se destaca e, que virá de encontro ao anseio da comunidade.

O jongo, portanto, é disseminado em contexto extra-escolar, isto é, os processos educativos referentes a ele ocorrem por meio da cultura. Sendo o jongo uma marca identitária importante, sugerimos como pauta de novos estudos a investigação da forma com que ele poderia adentrar os currículos e, consequentemente, transformar a escola em um projeto político da comunidade, o que poderia vir a refletir a possibilidade real de uma educação diferenciada para escolas situadas em áreas remanescentes de quilombos.

O encontro dos alunos com o jongo, além de manter a tradição folclórica secular, ratifica Duarte que afirma: "educar-se é, primeiramente, adquirir a "visão do mundo" da cultura a que se pertence; educar-se diz respeito ao aprendizado de valores e dos sentimentos que estruturam a comunidade na qual vivemos" (Duarte Junior 1995, p. 59).

E vai mais adiante:

Educar significa colocar o individuo em contato com os sentidos que circulam em sua cultura, para que, assimilando-os, ele possa nela viver. [...] permitir que ele conheça as múltiplas significações e as compreenda a partir de suas vivências. [...] novos significados, novas simbolizações, somente são aprendidas na medida em que se conectem a experiências de vida (Duarte Junior. 1995 p. $60)$.

Para melhor abranger 'os sentidos que circulam em sua cultura', é preciso abarcar a especificidade cultural a que propus, neste caso, o jongo. É preciso, destarte, compreender, esmiuçar, apontar dados e informações sobre este folguedo e, a partir de então, elaborarmos uma proposta de trabalho no Ensino das Artes Visuais.

\section{ANÁLISE DE DADOS}


No decorrer da pesquisa de campo, diversos foram os questionamentos feitos aos jongueiros, alunos na EMEF "Narciso Araújo" e à professora regente de classe. Os jongueiros mirins, por unanimidade, foram convidados a integrar a equipe pela Mestra Quequê, jongueira há mais de 50 anos, e a maioria não conhecia esta manifestação artística em Itapemirim, mesmo que centenária.

Os dados coletados com os alunos demonstraram certa preocupação: o jongo não é nem mesmo mencionado nas aulas de Arte, apesar de seu enraizamento na Região Sudeste e da obrigatoriedade de aplicabilidade da Lei $N^{\circ} 10.639 / 03$.

Questionada se saberia o que se comemora no dia 20 de novembro, a maioria dos alunos disse desconhecer, sabe, portanto, que a Escola periodicamente promove algum tipo de comemoração em datas específicas, mas não saberia defini-las.

$\mathrm{Na}$ abordagem feita se tinham conhecimento sobre a existência de tradições culturais predominantes, em especial, o jongo, na EMEF "Narciso Araújo", muitos disseram que não, mas que se lembravam de ter o visto o Grupo de Jongo Mirim “Chrispiniano Balbino Nazareth” participar do Desfile Escolar de 7 de Setembro tempos atrás.

Quanto às formas de representação de folclore que acontecem na escola em que estudam, alguns poucos afirmaram que participavam de quadrilhas caipiras e festas juninas, mas que, a atividade do jongo não era praticada no ambiente escolar, apesar de a maioria dos integrantes do jongo mirim estudar naquele Estabelecimento de Ensino.

Indagados sobre o aprendizado concernente às demais manifestações culturais afro-brasileiras, os estudantes foram unânimes em garantir que a escola aplica temas alusivos tanto na disciplina de Português (Língua Portuguesa e Literatura) quanto em Artes, mas que a falta de interesse em estudar sobre os motes propostos é de responsabilidade dos próprios alunos em sua multiplicidade.

À resposta dada surgiu uma ponderação: se considerasse que pouco se conhecia a respeito do jongo, como entenderiam ser possível ampliar seu conhecimento? A réplica foi silêncio universal! A entrevista prosseguiu arguindo se já haviam assistido a uma roda de jongo, haja vista que a presença do Grupo de Jongo Mirim "Chrispiniano Balbino Nazareth" no Desfile Escolar tinha sido apenas uma participação especial, ausentando-se o aparato necessário ao brilhantismo da manifestação artístico-cultural; 
onde e o que acharam? Exceção aos alunos que integram a equipe formada por Mestra Quequê, nenhum outro assistiu.

Ao investigar o que significa jongo, se, manifestação artístico-cultural ou que outra definição dariam e, qual seria esta consideração, excetuando-se, uma vez mais os integrantes do Grupo de Jongo Mirim "Chrispiniano Balbino Nazareth" que estudam na EMEF "Narciso Araújo", um número expressivo de alunos disse se tratar de macumba, "dança do Bicho Ruim".

A Mestra Quequê explanou sobre o jongo - dança e música de tradição quilombola, e comentou a luta dos jongueiros que, escravizados à época das grandes fazendas de café e cana-de-açúcar, e sua prática nos terreiros e senzalas para chorarem suas dores e tramarem, através de pontos enigmáticos, contra seus senhores.

Surgiu nova oportunidade de argumentar com os alunos e provocá-los a aprender um pouco mais sobre esta cultura na Escola, nas aulas de Artes, ao que parte dos expectadores passa demonstrar amplo interesse.

A esta altura os alunos passaram a identificar semelhanças e diferenças do conceito de arte que possuíam, estabelecendo elos entre jongo, arte e cultura. Aqueles que ainda estavam reticentes passaram a ratificar interesse em aprender mais e até arriscaram ensaiar passos e demandas. Outros foram mais além e assumiram que agregariam o grupo com o intuito de manter a tradição do folclore em Itapemirim.

\section{CONCLUSÕES}

O jongo é, senão a maior, uma das mais ricas manifestações da cultura popular afro brasileira e ainda enraizada em Itapemirim. Ao longo de décadas caiu no esquecimento, mas as crianças, incentivadas pela Mestra Quequê, jongueira de 65 anos, resgataram esta arte e a mesma precisa ser mantida para que ele e outras manifestações tragam cada vez mais a identidade de negros e negras conhecedores de sua cultura e de sua raiz.

Aplicar a teoria e a prática para os alunos da EMEF "Narciso Araújo" significou valorizar a cultura local, representou respeitar os antepassados e preservar o presente. Expressou uma forma de garantir que no futuro a arte não seja apenas cibernética, 
virtual ou existente apenas na memória de fotografia amareladas pelo tempo (se ainda houver fotografia).

Inseriu-se na sociedade itapemirinense o desejo de manter a tradição de bastante relevância à comunidade. Pais, alunos e comunidade perceberam a dimensão de resistência e articulação do jongo e compreendeu as práticas, formas e significados do jongo. Da periferia ao centro, em especial a comunidade "elitizada" entendeu a necessidade da interação e se transformou, produzindo assim identidades sociais, ressignificadas nas lutas cotidianas.

Enquanto marca identitária da Comunidade de Santo Antônio, a proposta de ensino/aprendizagem sobre o jongo em sala de aula foi muito bem aceita, no entanto, percebemos que crianças e adolescentes residentes nos bairros periféricos e na zona rural não demonstraram o mesmo interesse.

O jongo é, portanto, vivenciado, apreciado, aceito, praticado, querido por descentes de jongueiros, porém, acredito que com o passar do tempo mais e mais pessoas assimilarão a manifestação cultural e a aceitarão enquanto arte/cultura, se, a partir da Educação, for implantada, inserida, acrescida nas aulas de Artes informações a respeito do jongo e sua importância histórica em Itapemirim para os praticantes desta manifestação que descendem de jongueiros que muito contribuíram para a riqueza cultural da região.

O pensamento que se tem a respeito do jongo ainda remonta, não à escravidão e sua luta, sua arte, mas à prática de magia e, numa cidade onde um número expressivo de moradores é protestante, o fazer artístico através do jongo não é visto com bons olhos.

Houve sim, mudanças, aceitação, mas ainda é preciso trabalhar mais para que a ressignificação ocorra; para que a variação aconteça; para que a cultura se propague. Os estudantes querem, mas enquanto filhos de pais retrógrados e analfabetos culturais, se esbarram nos costumes ditatoriais, típicos de cidades provincianas.

\section{REFERÊNCIAS}

BARBOSA, A. M. (org.). Arteleducação contemporânea: consonâncias

BRAGA, Rubem. Um jongo entre os Maratimbas. In Revista do Arquivo Municipal. Ano VI, vol. LXVI, abril-maio. São Paulo: Publicação do Departamento de Cultura, 1940. 
DEWEY, J. Democracia e Educação. Introdução à Filosofia da Educação. São Paulo: Companhia Editora Nacional, 1959.

DUARTE JUNIOR, João Francisco. Fundamentos éticos da educação. Ed. Papirus. Campinas/SP, 1995.

GEERTZ, C. A interpretação das culturas. Rio de Janeiro: Guanabara Koogan, 1989.

GONÇALVES, L. A. O.; SILVA, P. B. G. O jogo das diferenças. O multiculturalismo e seus contextos. Belo Horizonte. Autêntica, 2006.

GUIMARÃES, A. A.; MOURA JUNIOR, C. da C. O terreiro, a roda e o ritual do jongo do sudeste brasileiro. In: CAMPOS, A. P.; GIL, A. C. A.; SILVA, G. V. da;

LARAIA, Roque de Barros. Cultura: um conceito antropológico. Ed. Jorge Zahar. Rio de Janeiro/RJ, 2004.

LOANGO, Anny Ocoro; OLIVEIRA, Marcos de Jesus; BORGES, Roberto Carlos da Silva. Diáspora Africana: ações presentes e perspectivas para o futuro. Revista da Associação Brasileira de Pesquisadores/as Negros/as (ABPN), [S.1.], v. 10, n. 26, p. 04-09, out. 2018. ISSN 2177-2770.

Disponível

em: <http://abpnrevista.org.br/revista/index.php/revistaabpn1/article/view/634>. Acesso em: 10 jan. 2019.

MAZOCO, Eliomar. Cultura popular capixaba: Breve perfil histórico. In: Espírito Santo - Um painel da nossa história. Secretaria de Educação do Espírito Santo. s/d.

MONTERO, P.; ARRUTI, J. M.; POMPA, C. Para uma antropologia do político. In:

NASCIMENTO, Rafael Cerqueira do; SANTOS, Luis Augusto dos. De Muribeca... ... a Presidente Kennedy, 2007;

OLIVEIRA, José Geraldo Mion. Jongo - do cativeiro aos dias atuais (saga de escravidão em miscelânea textual). Edição por Demanda, 2015;

SILVA, M. P. da. Novas diretrizes curriculares para o estudo da História e da Cultura afrobrasileira e africana: a Lei 10.639/03. EccoS, São Paulo, v. 9, n. I, p. 39-52, jan./jun. 2007. Disponível em http://www4.uninove.br/ojs/index.php/eccos/article/viewFile/486/468. Acesso em 08 de mar de 2012. 